\title{
Bioedusiana
}

http://jurnal.unsil.ac.id/index.php/bioed/index DOI: https://doi.org/10.34289/292824

\section{EKSPLORASI TUMBUHAN SUKU ORCHIDACEAE DI KAWASAN GUNUNG GALUNGGUNG KABUPATEN TASIKMALAYA SEBAGAI BAHAN AJAR TUMBUHAN TINGKAT TINGGI Exploration of Orchidaceae Plants in Galunggung Mount-Tasikmalaya as A Teaching Material in Higher Plants Subject}

\author{
Rinaldi Rizal Putra ${ }^{1,2)}$, Rita Fitriani ${ }^{1,2)}$ \\ ${ }^{1)} J u r u s a n$ Pendidikan Biologi FKIP Universitas Siliwangi, Jalan Siliwangi No. 24 Kota Tasikmalaya \\ ${ }^{2}$ Divisi Botani Kelompok Studi Biodiversitas dan Konservasi, Universitas Siliwangi \\ Email korespondensi: rinaldi.rizalputra@unsil.ac.id
}

\begin{tabular}{|c|c|}
\hline Info Artikel & Abstrak \\
\hline $\begin{array}{l}\text { Sejarah Artikel: } \\
\text { Diterima } 28 \text { September } \\
2019 \\
\text { Disetujui } 15 \text { November } \\
2019 \\
\text { Dipublikasikan } 1 \\
\text { Desember } 2019\end{array}$ & $\begin{array}{l}\text { Gunung Galunggung yang secara administratif masuk ke dalam wilayah Kabupaten Tasikmalaya menyimpan } \\
\text { berbagai kekayaan alam, khususnya pada aspek flora. Salah satu kekayaan flora yang berada di Gunung } \\
\text { Galunggung termasuk ke dalam suku Orchidaceae. Tumbuhan yang termasuk ke dalam suku Orchidaceae } \\
\text { memiliki jumlah spesies terbanyak dibandingkan tumbuhan berbunga lainnya, sehingga banyak diminati oleh } \\
\text { semua kalangan. Penelitian ini bertujuan untuk mengetahui jenis tumbuhan suku Orchidaceae di kawasan } \\
\text { Gunung Galunggung Kabupaten Tasikmalaya. Penelitian ini dilaksanakan pada bulan Mei s.d. September } 2019 \\
\text { di kawasan hutan Gunung Galunggung Kabupaten Tasikmalaya. Penelitian ini menggunakan metode deskriptif } \\
\text { dengan teknik pengamatan/eksplorasi langsung. Eksplorasi dilakukan dengan cara membagi lokasi menjadi tiga } \\
\text { stasiun pengamatan. Stasiun I berada pada ketinggian } 600 \text { s.d. } 800 \text { mdpl, Stasiun II berada pada ketinggian } 800 \\
\text { s.d. } 1000 \text { mdpl, dan StasiuBern III berada pada ketinggin } 1000 \text { s.d. } 1200 \text { mdpl. Teknik pengumpulan data } \\
\text { dilakukan dengan cara inventarisasi dan mengambil spesimen tumbuhan yang diduga Orchidaceae. Identifikasi } \\
\text { dilakukan secara morfologis dengan mencocokan pada buku panduan lapangan. Hasil dari penelitian ini } \\
\text { menunjukkan bahwa anggrek yang ditemukan di Gunung Galunggung berjumlah sepuluh spesies yang terdiri } \\
\text { dari anggrek epifit maupun anggrek terestrial. Diperlukan penelitian lebih lanjut untuk dapat mengeksplorasi } \\
\text { lebih banyak anggrek yang terdapat di kawasan Gunung Galunggung Kabupaten Tasikmalaya. }\end{array}$ \\
\hline
\end{tabular}

\begin{abstract}
Galunggung Mountain administratively is entered into Tasikmalaya districts that holds various natural resources, especially in the flora resources. One of the wealth of flora on Galunggung Mountain is included in the Orchidaceae family. Plants belonging to the Orchidaceae family have the highest number of species compared to other flowering plants, so they are in great demand by all people. This study aims to determine the types of plants of the Orchidaceae family in the Galunggung Mountain of Tasikmalaya district. This research was conducted in May to September 2019 in the Galunggung Mountain forest area, Tasikmalaya district. The method used in this research is descriptive method with direct observation / exploration techniques. Exploration is carried out by dividing locations into three observation stations: Station I, Station II, and Station III, which has an altitude of 600 - 800 masl, 800 - 1000 masl, and 1000 - 1200 masl, respectively. Data collection method carried out by inventorying and taking plant specimens suspected of Orchidaceae family. Morphological identification is carried out by matching it to the field manual. The results of this study indicates that the orchids found on Mount Galunggung amounted to ten species consisting of epiphytic orchids and terrestrial orchids. Further research is needed to be explore more orchids plants found in the Mount Galunggung, Tasikmalaya.
\end{abstract}

(C) 2019 Universitas Siliwangi ISSN: 2684-7604 (online) $\bowtie$ Alamat korespondensi: Jurusan Pendidikan Biologi FKIP Universitas Siliwangi Gedung Perkantoran FKIP Lt. 3

ISSN: $2477-5193$ (print)

Jalan Siliwangi No. 24 Kota Tasikmalaya 46115

HP. 08112344989 (a.n. Rinaldi Rizal Putra, M.Sc.)

E-mail: bioedusiana@unsil.ac.id 


\section{PENDAHULUAN}

Indonesia merupakan salah satu negara yang memiliki kawasan hutan terluas ketiga di dunia, setelah Brazil dan Kongo (Mahyar dan Sadili, 2003). Kekayaan alam yang terdapat di hutan Indonesia mencakup Sumber Daya Alam berupa fauna, flora, dan mikrobia yang tak terhingga jumlah dan nilainya. Ketersediaan yang melimpah dalam Sumber Daya Alam didukung oleh faktor habitat yang menunjang kehidupan berbagai biota. Pemanfaatan berbagai biota tersebut dapat berpotensi sebagai penghasil bahan pangan, bahan obat, dan bahan baku industri (Sutarno dan Setyawan, 2015). Salah satu kawasan hutan di Indonesia, khususnya di daerah Jawa Barat yang memiliki keragaman jenis biota cukup tinggi adalah kawasan Hutan Wisata Gunung Galunggung Kabupaten Tasikmalaya.

Menurut Pusat Vulkanologi dan Mitigasi Bencana Geologi Indonesia (2014), Gunung Galunggung ini secara administratif termasuk Priangan Tatar Sunda Kabupaten Tasikmalaya dan Garut dengan ketinggian $2.168 \mathrm{~m}$ di atas permukaan laut. Sejarah mencatat gunung ini pernah meletus sebanyak empat kali yaitu tahun 1822, 1894, 1918, dan 1982. Berkat keindahan alamnya gunung Galunggung merupakan salah satu ikon wisata Kabupaten Tasikmalaya yang selalu ramai dikunjungi baik oleh wisatawan lokal maupun mancanegara, namun tidak banyak yang mengetahui terutama mengenai keragaman jenis tumbuhan apa saja yang terdapat di kawasan gunung tersebut. Hal ini diperkuat juga dengan minimnya publikasi ilmiah jenis-jenis tumbuhan yang berada di kawasan gunung Galunggung ini.

Berdasarkan penelitian sebelumnya, diketahui bahwa di Gunung Galunggung telah ditemukan tumbuhan kantong semar dengan nama jenis Nepenthes gymnamphora yang ditemukan pada ketinggian 1.180 s.d. $1.200 \mathrm{mdpl}$ (Putra dan Fitriani, 2018). Namun, apabila ditelusuri lebih lanjut, selain $N$. gymnamphora belum ada lagi penelitian dan publikasi mengenai jenis tumbuhan lainnya yang terdapat di Gunung Galunggung. Hal tersebut menjadi perhatian tersendiri bagi kami selaku tim peneliti botani Jurusan Pendidikan Biologi FKIP Universitas Siliwangi untuk dapat melakukan eksplorasi lebih banyak mengenai keanekaragaman tumbuhan di kawasan Gunung Galunggung Kabupaten Tasikmalaya.

Selain penelitian mengenai identifikasi Nepenthes yang telah dilakukan sebelumnya, terdapat berbagai kelompok tumbuhan lain yang perlu mendapatkan perhatian, salah satunya adalah suku anggrek (Orchidaceae). Kelompok tumbuhan yang tergabung dalam suku Orchidaceae memiliki keunikan tersendiri, sehingga memiliki nilai ekonomis yang relatif stabil dibandingkan dengan suku tumbuhan lainnya. Keunikan yang terdapat pada golongan tumbuhan suku Orchidaceae antara lain terdapat pada bentuk bunga yang beragam, warna bunga yang mencolok, dan durasi mekarnya bunga yang relatif lama (Putra, R. R., et. al., 2016). Oleh karena itu, dengan keunikan tersebut, tidak asing bahwa tumbuhan suku Orchidaceae menjadi incaran para pemburu tanaman di habitat aslinya. Apabila hal ini dibiarkan, maka akan terjadi kelangkaan tumbuhan tersebut di habitat aslinya.

Selain karena keunikan tersebut, tanaman anggrek pun dapat digunakan untuk keperluan upacara adat, seperti yang diungkapkan oleh Ramdianti et. al. (2013) bahwa jenis anggrek kalajengking (Arachis flos-aeris) dimanfaatkan bunganya oleh masyarakat adat Kampung Pulo untuk upacara adat setempat.

Persebaran anggrek di Indonesia meliputi semua wilayah, mulai dari dataran rendah hingga pegunungan. Sadili (2011) menyebutkan bahwa persebaran anggrek di Taman Nasional Gunung Halimun-Salak Jawa Barat didapatkan 107 spesies, yang sebagiannya merupakan endemik Pulau Jawa. Kemudian, Manik et. al. (2017) menyebutkan bahwa suku Orchidaceae yang terdapat di kawasan Hutan Lindung Desa Sekendal teridentifikasi sebanyak 14 jenis yang sebagiannya bersifat epifit.

Salah satu upaya preventif yang dapat dilakukan dalam menjaga kelestarian tumbuhan suku Orchidaceae di habitat alaminya, dapat dilakukan dengan identifikasi dan inventarisasi melalui kegiatan eksplorasi. Hal ini bertujuan untuk mengetahui jumlah jenis tumbuhan suku Orchidaceae yang berada di habitat alaminya. Selain itu, upaya lanjutan yang dapat dilakukan melalui budidaya dengan teknik kultur in vitro menggunakan larutan agar sintetis sebagai media (Banks, 2003). 
Hasil dari penelitian ini diharapkan dapat menjadi referensi bagi peneliti lain yang akan melakukan penelitian mengenai tumbuhan suku Orchidaceae di kawasan Gunung Galunggung Kabupaten Tasikmalaya.

\section{METODE}

Penelitian ini dilakukan pada bulan Mei s.d. September 2019 di kawasan Gunung Galunggung Kabupaten Tasikmalaya. Metode yang digunakan dalam penelitian ini adalah deskriptif dengan teknik pengamatan/eksplorasi langsung. Eksplorasi dilakukan dengan cara membuat beberapa stasium pengamatan yang dibagi dalam tiga zona berbeda berdasarkan pada ketinggian, antara lain zona 1 (ketinggian 600 s.d. $800 \mathrm{mdpl}$ ), zona 2 (800 s.d. $1.000 \mathrm{mdpl}$ ), dan zona 3 (1.000 s.d. $1.200 \mathrm{mdpl}$ ).

Pada saat eksplorasi, dilakukan inventarisasi dan pengoleksian spesimen langsung dari lapangan. Inventarisasi anggrek dilakukan dengan tujuan untuk melihat kekayaan jenis anggrek di suatu kawasan (Puspitaningtyas, 2009). Pengambilan koleksi mengikuti metode Balgooy (1987), yaitu dengan cara menjelajah kawasan hutan yang dikunjungi.

Alat yang digunakan dalam penelitian ini meliputi Global Positioning System (GPS), kamera pocket, kotak spesimen, sasag, dan thermohygrometer. Kemudian, bahan yang digunakan antara lain tali rafia, alat tulis, alkohol teknis $96 \%$, gliserin teknis, akuades, dan buku panduan lapangan.

Data yang diperoleh dari lapangan didapatkan dengan cara inventarisasi anggrek, yang dilakukan dengan tujuan untuk melihat kekayaan jenis anggrek di suatu kawasan (stasiun). Identifikasi anggrek tingkat marga dilakukan dengan cara melakukan pengamatan pada aspek morfologis anggrek tersebut. Untuk mengidentifikasi sampai pada tingkat jenis, diperlukan pengamatan morfologi sampai pada organ bunganya. Jenis-jenis anggrek yang ditemukan di lapangan yang belum/tidak sedang berbunga hanya dapat diidentifikasi sampai tingkat marganya. Namun, beberapa jenis yang memiliki morfologi vegetatif yang khas dapat diidentifikasi sampai tingkat jenis meski sedang tidak berbunga.

\section{HASIL DAN PEMBAHASAN}

Kondisi vegetasi kawasan wisata Gunung Galunggung menyimpan banyak kekayaan flora dan fauna, khususnya flora yang tergolong ke dalam suku Orchidaceae. Selama melakukan pengamatan pada beberapa titik stasiun, kondisi lingkungan sangat mendukung untuk habitat tempat hidup berbagai jenis tumbuhan suku Orchidaceae. Berikut ini disajikan data mengenai kondisi lingkungan di hutan Gunung Galunggung sebagaimana yang terdapat pada Tabel 1 berikut.

Berdasarkan pada Tabel 1 tersebut, temperatur yang paling rendah berada pada suhu $20^{\circ} \mathrm{C}$, sedangkan paling tinggi berada pada suhu $29^{\circ} \mathrm{C}$. Kondisi demikian masih optimal untuk pertumbuhan dan perkembangan anggrek. Seperti yang dikemukakan oleh Assagaf (2012), bahwa anggrek dapat hidup di berbagai habitat dalam segala kondisi, dari mulai dataran rendah yang beriklim panas hingga dataran tinggi yang beriklim sejuk. Selain itu, anggrek pun dapat hidup pada kondisi temperatur berkisar $12^{\circ} \mathrm{C}$ hingga $35^{\circ} \mathrm{C}$.

Kondisi lingkungan sangat berpengaruh terhadap keberadaan dan pertumbuhan anggrek di suatu habitat. Suhu yang berimbas dari radiasi sinar matahari mampu mengubah kondisi kelembaban, dari kelembaban tinggi ke kelembaban rendah, begitu pun sebaliknya. Hal ini sesuai dengan yang dikemukakan oleh Jezek (2006), bahwa suhu mampu memengaruhi peningkatan dan penurunan kelembaban. Suhu dan kelembaban yang optimal mampu menginduksi anggrek untul menghasilkan perbungaan.

Berikutnya, berdasarkan hasil pengamatan di lapangan, sampai saat ini baru ditemukan 10 spesies anggrek dari 8 genus berbeda dengan total 100 individu. Dari tiga stasiun pengamatan, jenis anggrek tanah mendominasi dari keseluruhan jenis anggrek yang ditemukan. Berikut ini disajikan data pada Tabel 2 dan Gambar 1 mengenai jenis anggrek yang ditemukan selama pengamatan. 
Tabel 1. Kondisi lingkungan pada setiap stasiun pengamatan

\begin{tabular}{|c|c|c|c|c|}
\hline Stasiun & $\begin{array}{c}\text { Ketinggian } \\
\text { (mdpl) }\end{array}$ & $\begin{array}{c}\text { Kelembaban } \\
(\%)\end{array}$ & Suhu $\left({ }^{\circ} \mathrm{C}\right)$ & Deskripsi Lokasi \\
\hline $\mathrm{I}$ & $600-800$ & $72,5-90$ & $20,4-24$ & $\begin{array}{l}\text { Lokasi ini telah banyak diubah menjadi } \\
\text { destinasi wisata. Sebagian lokasi masih } \\
\text { ditumbuhi oleh pohon-pohon berukuran } \\
\text { besar dan beragam tumbuhan } \\
\text { pakupakuan, banyak terdapat aliran } \\
\text { sungai, dan kondisi tanah yang lembab. }\end{array}$ \\
\hline II & $800-1000$ & $65,7-86$ & $22-25$ & $\begin{array}{l}\text { Habitat didominasi oleh pepohonan } \\
\text { kaliandra dan tanah yang miring. Lokasi } \\
\text { banyak ditutupi oleh kanopi pohon, } \\
\text { sehingga kelembaban cukup tinggi dan } \\
\text { cenderung stabil. }\end{array}$ \\
\hline III & $1000-1200$ & $58,5-79$ & $21-29$ & $\begin{array}{l}\text { Lokasi banyak ditumbuhi oleh semak } \\
\text { belukar dan tumbuhan paku. Sebagian } \\
\text { lokasi dapat ditemukan pepohonan } \\
\text { berkayu dengan ukuran besar. Area ini } \\
\text { meliputi jalur pendakian dengan kontur } \\
\text { tanah miring, sehingga suhu dan } \\
\text { kelembaban dapat mengalami fluktuasi } \\
\text { yang cukup tinggi. Porositas tanah } \\
\text { sangat besar, karena didominasi oleh } \\
\text { tanah vulkanis. }\end{array}$ \\
\hline
\end{tabular}

Ket: Kondisi lingkungan pada semua stasiun diukur berdasarkan hari dan waktu yang sama

Tabel 2. Jenis Anggrek yang Ditemukan di Kawasan Gunung Galunggung Kabupaten Tasikmalaya

\begin{tabular}{|c|c|c|c|c|c|c|}
\hline \multirow{2}{*}{ No. } & \multirow{2}{*}{ Jenis Anggrek } & \multicolumn{3}{|c|}{ Stasiun } & \multirow{2}{*}{$\begin{array}{l}\text { Jumlah } \\
\text { Individu }\end{array}$} & \multirow{2}{*}{ Sifat Hidup } \\
\hline & & 1 & 2 & 3 & & \\
\hline 1. & Acriopsis javanica & - & - & 1 & 1 & Epifit \\
\hline 2. & Agrostophyllum sp. & - & - & 1 & 1 & Terestrial \\
\hline 3. & Arundina graminifolia & 1 & 4 & 43 & 47 & Terestrial \\
\hline 4. & Dendrobium mutabile & - & - & 2 & 2 & Epifit \\
\hline 5. & Dendrobium crumenatum & 2 & - & 2 & 5 & Epifit \\
\hline 6. & Malaxis versicolor & - & 3 & 1 & 4 & Epifit/terestrial \\
\hline 7. & Phaius tankervilleae & 2 & 4 & 21 & 27 & Terestrial \\
\hline 8. & Spathoglottis plicata & - & 2 & 6 & 8 & Terestrial \\
\hline 9. & Spathoglottis plicata var. alba & - & - & 1 & 1 & Terestrial \\
\hline 10. & Tainia sp. & - & 4 & - & 4 & Terestrial \\
\hline & Jumlah & 5 & 17 & 78 & 100 & \\
\hline
\end{tabular}

Berdasarkan data yang dikumpulkan dari lapangan, diketahui bahwa jenis anggrek yang ditemukan pada Stasiun I berjumlah dua spesies, yaitu dari jenis Dendrobium crumenatum dan Phaius tankervilleae. Berdasarkan data kondisi lingkungan pada Tabel 1, jumlah anggrek yang ditemukan hanya dua jenis ini diduga karena sebagian besar lokasi telah diubah menjadi destinasi wisata, walaupun pengelola tidak mengubah secara total komponen vegetasi di wilayah tersebut. Pepohonan yang berukuran cukup besar menjadi tempat hidup anggrek Dendrobium crumenatum atau yang lebih dikenal dengan anggrek merpati. Pepohonan menjadi tempat hidup anggrek ini karena secara alami, anggrek ini membutuhkan tempat yang cukup 
teduh hingga ketinggian $500-1.000$ mdpl (Mahyar dan Sadili, 2003), hingga $1.250 \mathrm{mdpl}$ (Ram et. al., 2015). Selain anggrek merpati, ditemukan juga anggrek Phaius tankervilleae yang hidup di permukaan tanah cukup lembab. Anggrek $P$. tankervilleae di Gunung Galunggung dapat ditemukan di semua stasiun dengan karakter tanah yang subur dan ditumbuhi oleh semak belukar (Assagaf, 2012). Selain di Gunung Galunggung, anggrek ini pun dapat ditemukan di Taman Nasional Gunung Halimun Jawa Barat (Mahyar dan Sadili, 2003).

Kemudian, pada Stasiun II ditemukan sebanyak 5 jenis anggrek dengan jumlah 17 individu. Pada stasiun ini, didominasi oleh Arundina graminifolia, Phaius tankervilleae dan Tainia speciosa, sedangkan jenis lainnya terdiri dari Malaxis versicolor dan Spathoglottis plicata.

Selanjutnya, pada Stasiun III, ditemukan 9 jenis anggrek, dengan didominasi oleh jenis $A$. graminifolia sebanyak 43 individu dan $P$. tankervilleae sebanyak 21 individu. Pada stasiun III ini, jenis anggrek yang ditemukan lebih banyak baik secara jumlah spesies maupun jumlah individu. Berdasarkan data lingkungan yang disajikan pada Tabel 1, diketahui bahwa kondisi tanah yang terdapat pada Stasiun III didominasi oleh tanah vulkanis dengan ukuran partikel tanah yang cukup besar.

Dominasi anggrek $A$. graminifolia dan $P$. tankervilleae pada Stasiun III sekaligus ditemukan di semua stasiun pengamatan diduga disebabkan oleh beberapa faktor. Faktor-faktor tersebut antara lain, ketersediaan air yang cukup dan terlindung oleh kanopi pepohonan di sekitarnya, terutama tumbuhan paku pohon. Selain itu, keberadaan semak belukar yang cukup rapat di sekitar tempat hidup $P$. tankervilleae diduga menjadi faktor terjaganya kelembaban lingkungan sekitar. Hal ini sesuai dengan pendapat Sufaati et. al. (2016) yang menjelaskan bahwa habitat anggrek $P$. tankervilleae umumnya ditemukan di kawasan cukup lembab dan tidak jauh dari sumber air. Selain itu, Vimal et. al. (2018) memperkuat bahwa anggrek $P$. tankervilleae merupakan salah satu tanaman anggrek yang cukup kuat untuk bertahan hidup dan menghasilkan bunga yang mekar selama bulan April hingga Juli. Hal tersebut sesuai dengan apa yang telah dilakukan, bahwa pengamatan anggrek yang dilaksanakan berlangsung pada waktu mekarnya bunga tanaman tersebut, sehingga pada bulan tersebut merupakan periode pertumbuhan puncak anggrek $P$. tankervilleae.

Kemudian, hasil eksplorasi berbagai macam jenis anggrek tersebut dapat dijadikan sebagai bahan ajar tumbuhan tingkat tinggi baik pada tingkat sekolah menengah atas hingga perguruan tinggi. Pada tingkat sekolah menengah atas, hasil penelitian ini dapat dijadikan suplemen pada materi Plantae, yang mengkaji aspek ciri-ciri umum plantae, peran tumbuhan dalam bidang ekonomi dan ekosistem, serta dampak berkurangnya keanekaragaman tumbuhan bagi ekosistem. Pada materi plantae dengan menggunakan suplemen hasil penelitian ini, peserta didik dapat mengamati dan membandingkan struktur alat reproduksi berupa bunga, yang menjadi pembeda antara satu spesies anggrek dengan spesies lainnya. Dengan membandingkan struktur morfologis bunga, peserta didik akan lebh memahami pengelompokkan tumbuhan sesuai dengan prinsip klasifikasi. Berikutnya, pada jenjang perguruan tinggi, hasil penelitian ini dapat dijadikan suplemen pada mata kuliah Taksonomi Tumbuhan Tingkat Tinggi. Pengelompokan tumbuhan tersebut didasarkan pada persamaan dan perbedaan karakteristik pada setiap jenis tumbuhan tersebut. 
Rinaldi Rizal Putra \& Rita Fitriani / Bioedusiana 4 (2) (2019)

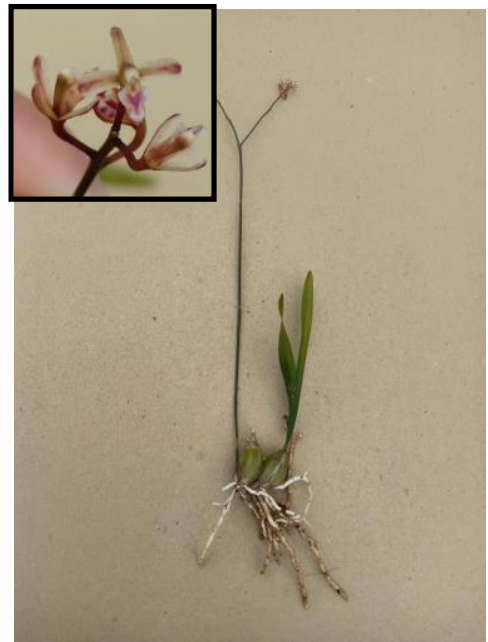

(a)

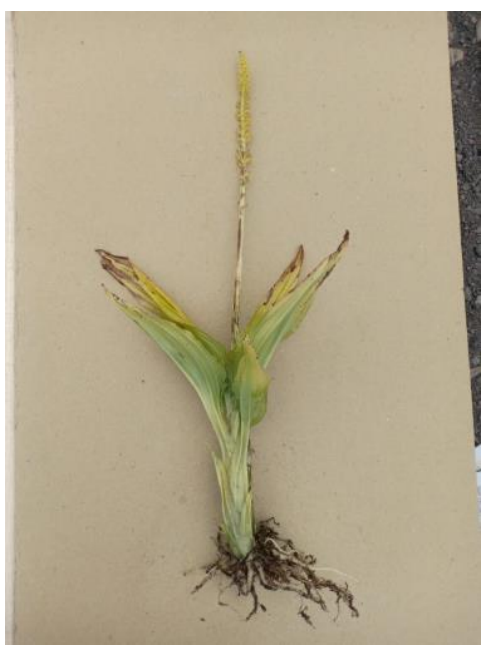

(d)

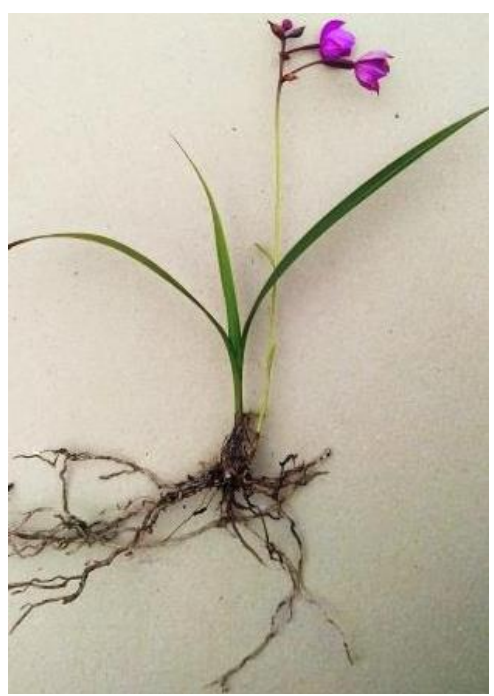

(g)

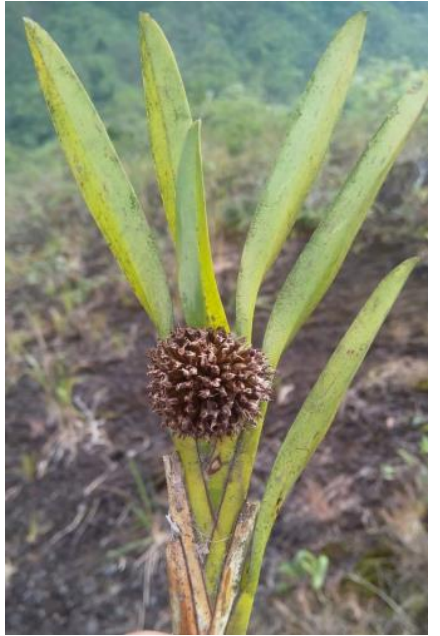

(b)

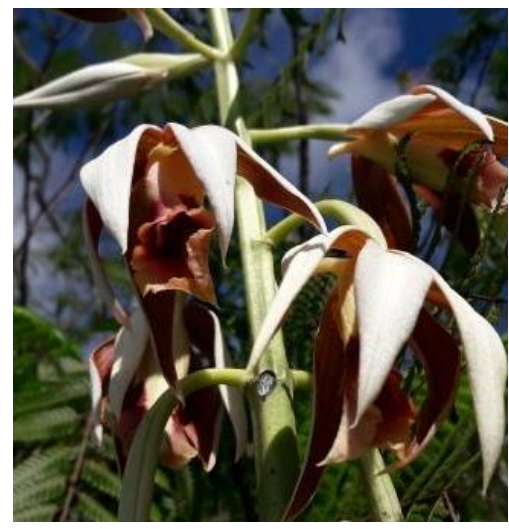

(e)

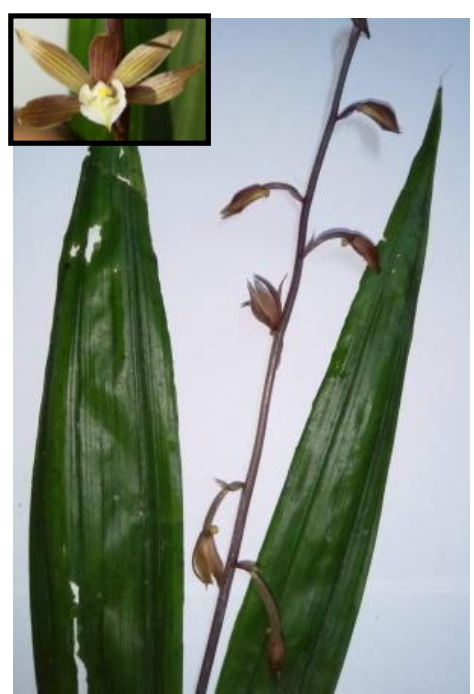

(h)

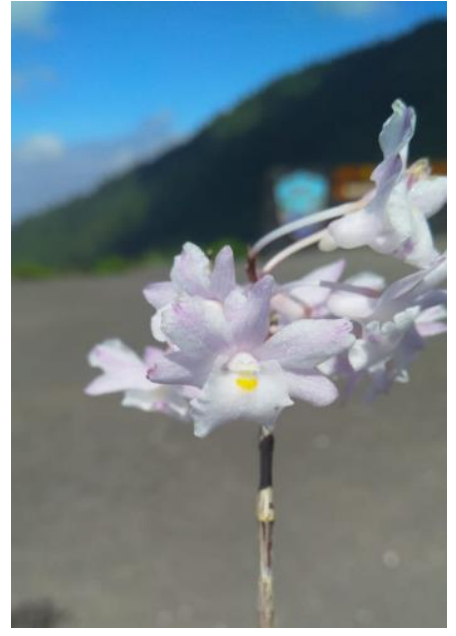

(c)

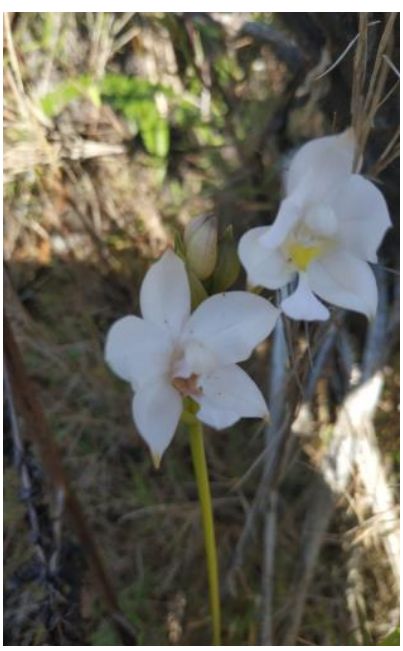

(f)

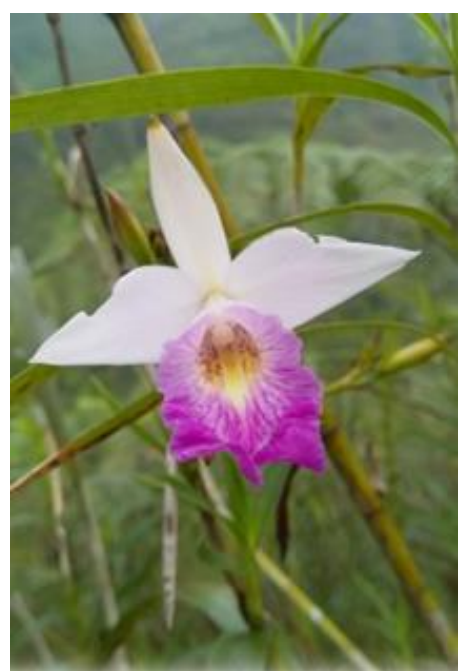

(i)

Gambar 1. Anggrek yang ditemukan di kawasan Gunung Galunggung Kabupaten Tasikmalaya:

(a) Acriopsis javanica; (b) Agrostophyllum sp.; (c) Dendrobium mutabile; (d) Malaxis versicolor; (e) Phaius tankervilleae; (f) Spathoglottis plicata var. alba; (g) Spathoglottis plicata; (h) Tainia sp.; (i) Arundina graminifolia 


\section{SIMPULAN, \\ SARAN, \\ DAN REKOMENDASI}

Tumbuhan anggrek yang terdapat di Gunung Galunggung telah teridentifikasi sebanyak 10 jenis yang terdiri dari Acriopsis javanica, Agrostophyllum sp., Arundina graminifolia, Dendrobium mutabile, Dendrobium crumenatum, Malaxis versicolor, Phaius tankervilleae, Spathoglottis plicata var. alba, Spathoglottis plicata, dan Tainia sp. Spesies yang paling mendominasi terdapat pada spesies Arundina graminifolia yang merupakan anggrek terestrial.

\section{UCAPAN TERIMA KASIH}

Ucapan terima kasih kami tujukan kepada LP2M-PMP Universitas Siliwangi yang telah memberikan hibah penelitian melalui program Penelitian Dosen Pemula yang didanai oleh DIPA Universitas Siliwangi Tahun 2019. Selain itu, kami mengucapkan terima kasih tak terhingga kepada tim peneliti Botani Kelompok Studi Biodiversitas dan Konservasi (KSBK) Universitas Siliwangi, antara lain kepada Dr. Diana Hernawani, M.Pd. selaku pembina KSBK, Asep Yudi Supriatna, S.Pd. dan Ari Hardian, S.Pd. selaku pranata laboratorium Pendidikan Biologi Universitas Siliwangi, serta Ibu Titi (owner Titi Orchid Yogyakarta). Juga kepada segenap mahasiswa yang telah membantu penelitian ini antara lain M. Irfan, Lia Lukita, Chyntia Anggita Lestari, Rifki Kurniadi, Putri Sabila, Fahmi M. Fauzi, dan Zihan Ayu Anggraeni.

\section{DAFTAR PUSTAKA}

Assagaf, M.H. (2012). 1001 Spesies Anggrek yang Dapat Berbunga di Indonesia. Jakarta: Penerbit Kataelha.

Balgooy, M.J.J. van. (1987). Collecting in: E.F. DeVogel, (Ed.), Manual of Herbarium Taxonomy: Theory and Practice. United Nations Educational, Scientific and Cultural Organitation Regional Office for Science and Technology for Southeast Asia. 14-19.

Banks, D.P. (2003). Handy Pocket Guide to The Orchids. Singapore: Periplus Editions.
Ježek, Z. (2006). The Complete Encyclopedia of Orchids. Netherlands: Rebo International b.v., Lisse.

Manik, F., R. Suryantini., dan H. Husni. (2017). Identifikasi Famili Orchidaceae di Kawasan Hutan Lindung Desa Sekendal Kecamatan Air Besar Kabupaten Landak. Jurnal Hutan Lestari, Vol. 5(2): 183 - 191.

Mahyar, U.W. dan A. Sadili. (2003). Jenis-jenis Anggrek Taman Nasional Gunung Halimun. Bogor: Biodiversity Conservation Project.

Puspaningtyas, D.M. (2009). Inventarisasi Keanakaragaman Anggrek di Suaka Alam Sulasih Talang - Sumatera Barat. Prosiding Keanekaragaman Hayati, pp. 174 $-181$.

Putra, R.R., Mercuriani, I.S., dan Semiarti, E. (2016). Pengaruh Cahaya dan Temperatur terhadap Pertumbuhan Tunas dan Profil Protein Tanaman Anggrek Phalaenopsis amabilis Transgenik Pembawa Gen Ubipro::PaFT. Bioeksperimen, Vol. 2(2), pp. $79-90$.

Putra, R.R. dan Fitriani, R. (2018). Identifikasi Morfologi Tumbuhan Kantong Semar (Nepenthes sp.) sebagai Bahan Ajar Tumbuhan Tingkat Tinggi di Kawasan Wisata Gunung Galunggung Kabupaten Tasikmalaya. Florea, Vol. 5(2), pp. 85 90.

Ram, A.T., M. Shamina, and A.K. Pradeep. (2015). Dendrobium crumenatum (Orchidaceae): A new record for mainland India. Rheedea, Vol 25(1): 69 71.

Ramdianti, N., H.A. Hidayah., dan Y. Widiawati. (2013). Kajian Etnobotani Masyarakat Adat Kampung Pulo di Kabupaten Garut. Biosfera, 30(1).

Sadili, A. (2011). Keanekaragaman, Persebaran, dan Pemanfaatan JenisJenis Anggrek (Orchidaceae) di Resort Citorek, Taman Nasional Gunung Halimun - Salak Jawa Barat. Biosfera, Vol. 28(1), pp. $15-22$. 
Sufaati, S., V. Agustini., dan Suharno. (2016).

Short Communication: Fusarium as

Endophyte of Some Terrestrial Orchid from Papua Indonesia. Biodiversitas, Vol. 17(1): $366-371$.

Sutarno dan Setyawan, A.D. (2015). Biodiversitas Indonesia: Penurunan dan Upaya Pengelolaan untuk Menjamin Kemandirian Bangsa. Pros. Semnas Masyarakat Biodiversitas Indonesia, Vol. 1(1), pp. $1-13$.

Vimal, S., M.C. Nisha., and S. Rajesh-Kumar. (2018). In Vitro Propagation of Phaius Tankervilleae (Banks) Blume. International Journal of Innovative Science and Research Technology, Vol. 3(11), $805-808$. 